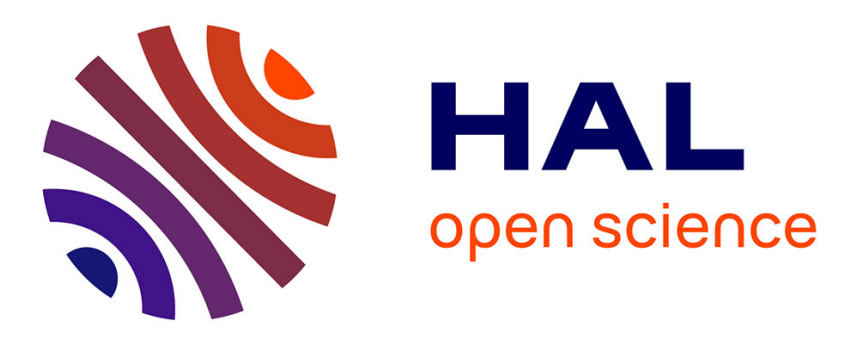

\title{
First serological and molecular evidence on the endemicity of and in Hungary
}

Sándor Hornok, Vilmos Elek, José de La Fuente, Victoria Naranjo, Róbert

Farkas, Gábor Majoros, Gábor Földvári

\section{- To cite this version:}

Sándor Hornok, Vilmos Elek, José de La Fuente, Victoria Naranjo, Róbert Farkas, et al.. First serological and molecular evidence on the endemicity of and in Hungary. Veterinary Microbiology, 2007, 122 (3-4), pp.316. 10.1016/j.vetmic.2007.01.024 . hal-00532200

\section{HAL Id: hal-00532200 \\ https://hal.science/hal-00532200}

Submitted on 4 Nov 2010

HAL is a multi-disciplinary open access archive for the deposit and dissemination of scientific research documents, whether they are published or not. The documents may come from teaching and research institutions in France or abroad, or from public or private research centers.
L'archive ouverte pluridisciplinaire HAL, est destinée au dépôt et à la diffusion de documents scientifiques de niveau recherche, publiés ou non, émanant des établissements d'enseignement et de recherche français ou étrangers, des laboratoires publics ou privés. 


\section{Accepted Manuscript}

Title: First serological and molecular evidence on the endemicity of Anaplasma ovis and A. marginale in Hungary

Authors: Sándor Hornok, Vilmos Elek, José de la Fuente, Victoria Naranjo, Róbert Farkas, Gábor Majoros, Gábor

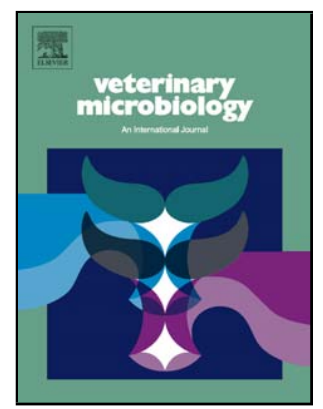
Földvári

PII: S0378-1135(07)00062-4

DOI: doi:10.1016/j.vetmic.2007.01.024

Reference: VETMIC 3579

To appear in: $\quad$ VETMIC

Received date: $\quad$ 21-12-2006

Revised date: 26-1-2007

Accepted date: $\quad$ 29-1-2007

Please cite this article as: Hornok, S., Elek, V., de la Fuente, J., Naranjo, V., Farkas, R., Majoros, G., Földvári, G., First serological and molecular evidence on the endemicity of Anaplasma ovis and A. marginale in Hungary, Veterinary Microbiology (2007), doi:10.1016/j.vetmic.2007.01.024

This is a PDF file of an unedited manuscript that has been accepted for publication. As a service to our customers we are providing this early version of the manuscript. The manuscript will undergo copyediting, typesetting, and review of the resulting proof before it is published in its final form. Please note that during the production process errors may be discovered which could affect the content, and all legal disclaimers that apply to the journal pertain. 
1 8

\section{First serological and molecular evidence on the endemicity of Anaplasm a ovis and A. marginale in Hungary}

3

(1)

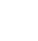

6

(1)

8

9

10

1

2

3

4

5

16
7 Sándor Hornok ${ }^{\mathrm{a}^{*}}$, Vilmos Elek $^{\mathrm{b}}$, José de la Fuente $^{\mathrm{c}, \mathrm{d}}$, Victoria Naranjo ${ }^{\mathrm{c}}$, Róbert Farkas ${ }^{\mathrm{a}}$, Gábor Majoros $^{\mathrm{a}}$, Gábor Földvári $^{\mathrm{a}}$
${ }^{\mathrm{a} D e p a r t m e n t ~ o f ~ P a r a s i t o l o g y ~ a n d ~ Z o o l o g y, ~ F a c u l t y ~ o f ~ V e t e r i n a r y ~ S c i e n c e, ~}$ Szent István University, István u. 2., 1078 Budapest, Hungary
${ }^{\mathrm{b} C o u n t y}$ Veterinary Station, Borsod-Abaúj-Zemplén, Vologda u. 1., 3525 Miskolc, Hungary
${ }^{\mathrm{d}}$ Department of Veterinary Pathobiology, Center for Veterinary Health Sciences, Ok lahoma
${ }^{\mathrm{c} I n s t i t u t o ~ d e ~ I n v e s t i g a c i o ́ n ~ e n ~ R e c u r s o s ~ C i n e g e ́ t i c o s ~ I R E C, ~}$ Ronda de Toledo, 13071 Ciudad Real, Spain
* Corresponding author. Tel.: 36-1-478-4187, Fax: 36-1-478-4193
E-mail address: Hornok.Sandor@aotk.szie.hu




\section{Abstract}

26

Recurring and spontaneously curing spring haemoglobinuria was recently reported in a small sheep flock in a selenium deficient area of northern Hungary. In blood smears of two animals showing clinical signs, Anaplasma-like inclusion bodies were seen in erythrocytes. To extend the scope of the study, 156 sheep from 5 flocks and 26 cattle from 9 farms in the region were examined serologically with a competitive ELISA to detect antibodies to Anaplasma marginale, A. centrale and A. ovis. The seropositivity in sheep was $99.4 \%$, and in cattle $80.8 \%$. A. ovis and A. marginale were identified by PCR and sequence analysis of the major surface protein $(m s p) 4$ gene in sheep and cattle, respectively.

Haemoglobinuria, an unusual clinical sign for anaplasmosis might have been a consequence of transient intravascular haemolysis facilitated by selenium deficiency in recently infected sheep, as indicated by the reduction of mean corpuscular haemoglobin concentration (MCHC). Membrane damage was also demonstrated for parenchymal cells, since their enzymes showed pronounced elevation in the plasma. Ticks collected from animals in the affected as well as in neighbouring flocks revealed the presence of Dermacentor marginatus, Ixodes ricinus and D. reticulatus, with the dominance of the first.

The present data extend the northern latitude in the geo graphical occurrence of ovine anaplasmosis in Europe and reveal the endemicity of A. ovis and A. marginale in Hungary.

Keywords: Anaplasmosis; Dermacentor; Ixodes; tick; haemo globinuria; selenium deficiency 
50

51

52

53

54

55

56

57

58

\section{Introduction}

Representatives of the genus Anaplasma belong to the order Rickettsiales and are obligate intracellular etiological agents of tick-borne diseases of mammals. In red blood cells of ruminants three closely related species occur: the most pathogenic A. marginale and the less pathogenic $A$. centrale in cattle, and the moderately pathogenic $A$. ovis in small ruminants (Kuttler, 1984; Lew et al., 2003). Although anaplasmosis is more frequently associated with haemolytic anaemia in goats, A. ovis can also cause disease in sheep, particularly in animals exposed to stress or other predisposing factors (Splitter et al., 1956; Friedhoff, 1997).

In Europe the geographical distribution of ovine anaplasmosis is restricted to the southern countries, including France (Cuille and Chelle, 1936), Italy (de la Fuente et al., 2005), Turkey (Sayin et al., 1997), Greece (Papadopoulos, 1999), Bulgaria (Christova et al., 2003) and Southeast Romania (Ardeleanu et al., 2003). Similarly, A. marginale is endemic mainly to the Mediterranean-Balkanian countries: France (Poncet et al., 1987), Spain and Portugal (de la Fuente et al., 2004; Caeiro, 1999), Italy (de la Fuente et al., 2005), but it has also been reported in the northern latitude of the Alpean region (Baumgartner et al., 1992; Dreher et al., 2005a). In Hungary only sporadic occurrence of bovine anaplasmosis was recognized in an imported herd of cattle (Dankó et al., 1982).

During the past few years recurring, transient spring haemoglobinuria was noted in a small flock of sheep in a selenium deficient area of northern Hungary. The aim of the present study was to find the causative agent, and to collect relevant data on local sheep flocks and cattle. 
75

76

77

78

79

80

81

84

5

\section{Materials and methods}

\subsection{Clinic al h istory and sample collection}

The small flock of Merino sheep in the present study consists of 37 animals that have been kept in Domaháza in northern Hungary for the past 5 years, and prior to that in a neighbouring village. No animals were introduced from outside this area.

In the spring of 2006 samples were collected as soon as the notification on clinical signs was received from the local veterinarian. Fresh anticoagulated (EDTA-containing and heparinized) blood was taken from two sheep (A and B) noted with haemoglobinuria this year (from sheep A 2 and 24 days, from sheep B 2 days after the appearance of clinical signs) and from three randomly selected others (C-E) at the same time as from sheep B. Serum samples were collected from all animals in this and from 119 sheep in four neighbouring flocks (kept within a distance of $1 \mathrm{~km})$. Serum and blood samples were also obtained from 26 local cattle (Hungarian Pied, from 9 farms) grazing the same pastures. The age of the animals was ascertained whenever possible.

Ticks were removed from at least $30 \%$ of sheep in this as well as in 12 other flocks of the region (within $50 \mathrm{~km}$ ) for species identification.

\subsection{Clinic al laboratory procedures}

Thin blood films were prepared from samples of sheep A and B, fixed with methanol and stained with Giemsa. Haematological values were determined using an Abacus haematology analyser (Diatron GmbH, Vienna, Austria), and biochemical parameters with an 
99

100

101

102

103

104

105

106

107

108

109

110

111

112

113

114

115

116

117

118

119

120

121

122

123

au tomatic spectrophotometer (RX Daytona, Randox Laboratories Ltd., Crumlin, UK). Stained blood smears were also made from samples of cattle included in this survey.

\subsection{Serology for Anaplasma spp.}

A competitive enzyme-linked immunosorbent assay (cELISA) was performed with samples of 156 sheep and 26 cattle using the Anaplasma Antibody Test Kit from VMRD Inc. (Pullmann, WA, USA) following the manufacturer's instructions. This assay detects serum antibodies to a major surface protein (MSP5) of A. marginale, A. centrale, A. ovis and A. phagocytophilum. Although approved only for bovines by the U.S. Department of Agriculture, it could detect seroconversion of experimentally infected sheep, since their antibodies compete successfully for free binding sites with monoclonal antibodies present in the detection system of the test kit (Dreher et al., 2005b). Optical density (OD) values were determined using an automatic Multiscan Plus microplate reader (model RS-232 C, Labsystems, Helsinki, Finland), and the percentage of inhibition was calculated as follows: I $(\%)=100-($ sample OD x 100) $/($ mean OD of three negative controls). Samples with an inhibition $\geq 30 \%$ were regarded positive.

\subsection{Molecular bio logy}

\subsubsection{DNA extraction}

DNA was extracted from $200 \mu \mathrm{l}$ amounts of EDTA blood from 5 seropositive sheep (A-E) and 12 (including 2 seronegative) cattle using QIAamp DNA blood mini kit (QIAGEN, Hilden, Germany) according to the manufacturer's instructions. 


\subsection{2. msp4 polymerase chain reaction (PCR) and sequencing}

The Anaplasma spp. msp4 gene was amplified by PCR and sequenced as reported previously (de la Fuente et al., 2005; 2007). For sheep samples, $1 \mu$ (1-10 ng) DNA was used with 10 pmol of each primer (A. marginale/A. ovis:

MSP45: 5'GGGAGCTCCTATGAATTACAGAGAATTGTTTAC3' and

\section{MSP43: 5'CCGGATCCTTAGCTGAACAGGAATCTTGC3'; A. phagocytophilum:} performed in an automated DNA thermal cycler (Techne model TC-512, Cambridge, England, UK) for 35 cycles. After an initial denaturation step of $30 \mathrm{sec}$ at $94^{\circ} \mathrm{C}$, each cycle consisted of a denaturing step of $30 \mathrm{sec}$ at $94^{\circ} \mathrm{C}$, an annealing for $30 \mathrm{sec}$ at $60^{\circ} \mathrm{C}$ and an extension step of $1 \mathrm{~min}$ at $68^{\circ} \mathrm{C}$ for $A$. marginale/A. ovis and an annealing-extension step of 1 min at $68^{\circ} \mathrm{C}$ for $A$. phagocytophilum. Negative control reactions were performed with the same procedures, but adding water instead of DNA to monitor contamination of the PCR. The program ended by storing the reactions at $10^{\circ} \mathrm{C}$. PCR products were electrophoresed on $1 \%$ agarose gels to check the size of amplified fragments by comparison to a DNA molecular weight marker (1 Kb DNA Ladder, Promega). Amplified fragments were resin purified

145 (Wizard, Promega) and cloned in to the pGEM-T vector (Promega) for sequencing both 146 strands by double-stranded dye-termination cycle sequencing (Secugen SL, Madrid, Spain).

147 At least two independent clones were sequenced for each PCR.

148 For cattle samples, the same primers were used as for the sheep samples (de la Fuente 149 et al., 2005; 2007) with some differences in the PCR and sequencing. One $\mu 1$ (1-10 ng) of 
extracted DNA was added to a $49 \mu \mathrm{l}$ reaction mixture comprised of $10 \mathrm{pmol}$ of each primer, $1.5 \mathrm{mM} \mathrm{MgCl}_{2}, 0.2 \mathrm{mM}$ dNTP, $5 \mu 1$ 10× PCR buffer and $5 \mathrm{u}$ of GoTaq Flexi DNA polymerase

152 (all Promega). Amplification was performed using a Tpersonal 48 thermal cycler (Biometra

$153 \mathrm{GmbH}$, Göttingen, Germany) under the same conditions as with ovine samples. Amplified 154 DNA was subjected to electrophoresis in a $1 \%$ agarose gel $(100 \mathrm{~V}, 40 \mathrm{~min})$, pre-stained with 155 ethidium bromide and viewed under ultra-vio let light. After purification with Wizard ${ }^{\circledR}$ SV gel 156 and PCR clean-up system (Promega), ABI Prism ${ }^{\circledR}$ Big Dye Terminator v3.1 Cycle 157 Sequencing Kit (Perkin-Elmer, Applied Biosystems Division, Foster City, CA, USA) was 158 used for DNA sequencing reactions. Samples were then examined using an ABI Prism ${ }^{\circledR} 3100$

159 Genetic Analyser at the Agricultural Biotechnology Center Gödöllö, Hungary.

\subsubsection{Sequence ana lysis}

162

Obtained sequences were checked with Chromas v.1.45 and compared to sequence data available from GenBank $^{\circledR}$, using the BLAST 2.2.15. program

165 (http://www.ncbi.nlm.nih.gov/BLAST/). Multiple sequence alignment was performed using the program AlignX (Vector NTI Suite V 5.5, Invitrogen, North Bethesda, MD, USA) with an engine based on the Clustal W algorithm (Thompson et al., 1994). Nucleotides were coded as unordered, discrete characters with five possible character states: A, C, G, T or N and gaps were coded as missing data.

\subsubsection{Sequence accession numbers}




\subsection{Statistical analysis}

178 Exact confidence intervals for the prevalence rates were calculated according to Sterne's method. Data were compared by using Fisher's exact test, and means of inhibition values by $t$-test. Differences were regarded significant when $\mathrm{P} \leq 0.05$.

183

184

\section{Results}

\subsection{Clinic opathological and haematological findings}

In each year, usually in May a few sheep of the examined flock showed haemoglobinuria that lasted for 1-3 days and then ceased spontaneously. In 2006 only two animals were noted with such transient clinical signs: sheep A in April and sheep B in May. In blood smears of sheep A and B very few $(<1 \%)$ erythrocytes contained one or more small $(<1 \mu \mathrm{m})$ round, dark staining bodies on the periphery (submarginally), suggestive of infection with Anaplasma sp.. Regarding haematological parameters, only reduction of mean corpuscular haemoglobin concentration (MCHC: normal value 310-340 g/l) could be demonstrated in the two sheep with noted haemoglobinuria (277 and $295 \mathrm{~g} / \mathrm{l}$, respectively). Biochemical analysis showed pronounced elevation of plasma levels of aspartate aminotransferase (AST) and alanine aminotransferase (ALT) in all three examined animals (A, B and C), and of alkaline phosphatase (ALP), gamma-glutamyl transpeptidase (GGT) in sheep A and B (Table 1). Total protein was slightly increased. Other values were within their normal range (data not shown). 
In blood smears of examined cattle the percentage of infected erythrocytes was low $(<$

201

202

203

204

205

206

207

208

209

210

211

212

213

214

215

216

217

218

219

220

221

222

223

224

$3 \%$ ), and they contained 1-2 inclusion bodies in marginal, submarginal or central position

(with equal approximated proportion). No relevant clinical signs were observed in these cattle during the past years.

\subsection{Serological and molecular characterization of Anaplasma infections}

Seroprevalence of anaplasmosis in five local flocks of sheep was 99.4\% (CI: 96.5$100 \%$ ), as 155 of 156 animals had inhibition values $\geq 30 \%$, decreasing with the advance of age (Table 2). This implies that $1-2$ year old sheep had a significantly $(\mathrm{P}<0.005)$ higher mean antibody level when compared to that of 6-10 year old sheep. In the cELISA $80.8 \%$ (21 of $26, \mathrm{CI}: 60.7-93.5 \%$ ) of local cattle were also found positive.

A. phagocytophilum was not detected in analysed samples. The Anaplasma spp. msp4 gene was successfully amplified from all 5 ovine samples. Sequence analysis of the PCR products established that all of them correspond to A. ovis, differring from each other and from those found in GenBank in some positions (Table 3). The only exception was EF 190511 which showed $100 \%$ sequence identity to A. ovis obtain ed from Sicilian sheep (AY702923).

The Anaplasma spp. msp4 gene was also successfully amplified from 4 of the 12 bovine samples. One of them was sequenced, revealing $99.4 \%$ similarity to an A. marginale sequence deposited in GenBank (AY127073).

\subsection{Ticks collected from sheep and cattle}

The most dominant tick species found during the spring in the affected sheep flock was Dermacentor marginatus (95.9\%: 70 of 73 ), followed by Ixodes ricinus (2.7\%: 2 of 73 ) 
225

226

227

228

229

230

231

232

233

234

235

236

237

238

239

240

241

242

243

244

245

246

247

248

and D. reticulatus (1.4\%: 1 of 73$)$. This prevalence of $D$. marginatus was not significantly different from that observed in other parts of the region (92.8\%: 346 of 373).

The predominant tick species found on local cattle in the autumn was D. reticulatus (data not shown).

\section{Discussion}

This is the first report of ovine anaplasmosis in Hungary. Haemoglobinuria in the relevant sheep flock (according to its seasonality) was suspected to be the effect of a tickborne pathogen. Although data are not available on the occurrence of ovine babesiosis or theileriosis in Hungary, in the present survey the etiological role of piroplasms was excluded by PCR (data not shown). Anap lasmosis was diagnosed on the basis of erythrocyte inclusion bodies seen in blood smears of local sheep (and cattle), and their high rate of seropositivity to Anaplasma spp. in the cELISA, but the causative agent could not be identified with these methods, as A. marginale can also infect sheep (Kuttler, 1984; Sharma, 1988). Additionally, in order to exclude from the prevalence rates seropositivity due to cross-reacting $A$. phagocytophilum (Dreher et al., 2005b), two msp4 PCR assays were applied: one specific for A. marginale/A. ovis (primers MSP45 and MSP43), and another for A. phagocytophilum (primers MSP4AP5 and MSP4AP3) (de la Fuente et al., 2005). Identification of the species was done by sequence analysis of msp 4 amplicons (de la Fuente et al., 2005) which revealed the presence of $A$. ovis in sheep and A. marginale in cattle, according to their typical hosts (Kuttler, 1984). The sequence heterogeneity between the five Hungarian A. ovis isolates suggest that msp4 genotypes may vary not only among geographic regions and different hosts (de la Fuente et al., 2007), but also between individual sheep of the same flock. 

diagnosed in an imported herd (Dankó et al., 1982). Those animals were successfully treated, clinical signs disappeared, and no data on the occurrence of $A$. marginale have since been 252 reported in this country. Cattle of the present survey never left the region and were not 253 brought in from abroad, therefore this is the first recognition of an endemic focus and of the autochthonous infection of cattle with A. marginale in Hungary. Since bovine anaplasmosis frequently has a fatal outcome or necessitates culling of affected animals (Dreher et al., 2005a), absence of relevant clinical signs in cattle of the study area suggests that the causative agent is a less virulent strain that has been present for several years, allowing the reduction of 258 pathogenicity.

On the other hand, ovine anaplasmosis is usually a benign disease, but predisposing factors may aggravate or influence its manifestation (Friedhoff, 1997). This should be taken into account when considering the present results, as all studied animals were kept in a selenium deficient area (Hajtós, 1982). Selenium deficiency is known to have an immunosuppressive effect and promotes susceptibility to bacterial diseases (Van Vleet, 1980). Haemoglobinuria is an unusual clinical sign of anaplasmosis, because anaemia results

265 from extravascular opsonization and phagocytosis of parasitized erythrocytes by 266 reticuloendothelial cells (Allen et al., 1981). However, in case of sheep in the present study a 267 significant role of this mechanism can not be substantiated, because affected animals did not 268 become anaemic, and their total bilirubin concentration was within the normal range. On the contrary, a transient intravascular haemolys is might have occurred when red blood cells were

270 exposed to freshly inoculated $A$. ovis, which was facilitated by selenium deficiency, making 271 erythrocyte membranes more vulnerable (Rotruck et al., 1972). Anaplasma marginale was 272 also shown to induce downregulation of enzymes that have a selenium-dependent nature and 273 are important in the oxidant defence system of erythrocytes (Reddy et al., 1988; More et al., 
274 1989), thus the two factors may have acted synergistically. Similarly, haemoglobinuria in 275 ruminants with intraerythrocytic infectious agents was reported to be associated with 276 oxidative stress to erythrocytes (Sahoo et al., 2001).

277 Mild pathogenicity of $A$. ovis was further reflected by the low number of sheep noted 278 with haemoglobinuria, although this may have been influenced by differences between the 279 flocks (e.g. whether they were continuously monitored or not). Most haematological 280 parameters also remained within the normal range. In accordance with the present results 281 decreased MCHC level during ovine anaplasmosis was reported previously (Ramprabhu et 282 al., 1999). The blood chemistry values obtained in our study suggest pathological changes in 283 the liver and in muscles, but not in the kidney. Both selenium deficiency (Bickhardt et al., 284 1999) and anaplasmosis (Allen et al., 1981) may induce elevation of AST and ALP, therefore 285 this is most likely attributable to a combined effect of the two. In contrast to 286 hypoproteinaemia frequently observed in case of sheep with selenium deficiency (Bickhardt 287 et al., 1999), the slight elevation in total protein level may have indicated humoral immune 288 response to $A$. ovis (hyperglobulinaemia). This was further justified by finding all except one 289 examined sheep seropositive in the area. The significant decrease of antibody levels with the 290 advance of age, the low percentage of infected erythrocytes compared to other reports 291 (Splitter et al., 1956; Allen et al., 1981), PCR negativity of 6 seropositive cattle and the 292 absence of clinical signs in most sheep as well as cattle may be associated with the carrier 293 state of these animals. Anaplasmosis usually progresses to a lifelong persistent and subclinical 294 infection (Palmer et al., 1998; Kieser et al., 1990), simultaneously providing the source for 295 tick-borne transmission of the pathogen (Kocan et al., 2003). This may also explain the 296 extremely high prevalence of ovine anaplasmosis in our study as observed by others 297 (Shompole et al., 1989), and makes it probable that in the same area both $A$. ovis and $A$. 298 marginale might be present in wildlife reservoirs too (Kuttler, 1984; de la Fuente et al., 2004). 
300 found on sheep in the affected flock, mainly Dermacentor marginatus could be implicated in

301 the transmission of $A$. ovis in northern Hungary. However, the vector of this species is

302 unknown in many regions of the world (Friedhoff, 1997). The occurrence of tick species in

303 more distant sheep of the region did not differ significantly from that in the affected flock,

304 and lambs are regularly exported to other parts of Hungary, therefore monitoring of ovine

305 anaplasmosis should be extended to a larger area in the country. Whether this stable endemic

306 focus indicates a unique case, or on the contrary, it reflects a northward expansion of the

307 geographical distribution of $A$. ovis, needs further investigation.

308

309 Acknowledgements

310

311 This research was partially supported by the grant "Epidemiología de zoonosis transmitidas

312 por garrapatas en Castilla - La Mancha" (06036-00 ICS-JCCM). V. Naranjo is funded by

313 Junta de Comunidades de Castilla - La Mancha (JCCM), Spain. The authors would like to

314 acknowledge the advice of Martin J. Kenny (University of Bristol, UK). Without the

315 contributions of J. Elek and I. Hajtós this work could not be done.

316

\section{References}

318

319 Allen, P.C., Kuttler, K.L., Amerault, B.S., 1981. Clinical chemistry of anaplasmos is: blood

320 chemical changes in infected mature cows. Am. J. Vet. Res. 42, 322-325. 
322

\section{3}

324

325

326

327

328

329

330

331

332

333

334

335

336

337

338

339

340

341

342

343

344 Cuille, J., Chelle, P.L., 1936. L'anaplasmose du mouton en France. Rev. gen. Med. Vet. 45, $345 \quad 129-140$.

Ardeleanu, D., Neacsu, G.M., Pivoda, C.A., Enciu, A., 2003. Structure of polyparasitism on sheep in Dobrudja. Buletinul Universitatii de Stiinte Agricole si Medicina Veterinara Cluj

Napoca, Seria Medicina Veterinara 60, 28-32. (in Roman)

Arthur, D.R., 1960. Ticks: a monograph of the Ixodoidea part V.- Cambridge University

Press, Cambridge, UK p. 150.

Baumgartner, W., Schlerka, G., Fumicz, M., Stöger, J., Awad-Masalmeh, M., Schuller, W., Weber. P., 1992. Seroprevalence survey for Anaplasma marginale infection of Austrian cattle. J. Vet. med. B 39, 97-104.

Bickhardt, K., Ganter, M., Sallmann, P., Fuhrmann, H., 1999. Investigations on manifestations of vitamin E and selenium deficiency in sheep and goats. Dtsch. Tierarztl.

Wochenschr. 106, 242-247.

Caeiro, V., 1999. General review of tick species present in Portugal. Parassitologia 1 (Suppl. 41), 11-15.

Christova, I., Pol, J. van de, Yazar, S., Velo, E., Schouls, L., 2003. Identification of Borrelia burgdorferi sensu lato, Anaplasma and Ehrlichia species, and spotted fever group rickettsiae in ticks from Southeastern Europe. Eur. J. Clin. Microbiol. Inf. Dis. 22, 535-542. 
Dankó, Gy., Szilágyi, M., Nádházy, L., 1982. Anaplasmosis in a Hungarian cattle herd.

348 Magy. Állatorvosok. 37, 80-83. (in Hungarian)

349

350 de la Fuente, J., Vicente, J., Hofle, U., Ruiz-Fons, F., Fernández de Mera, I.G., van den

351 Bussche, R.A., Kocan, K.M., Gortazar, C, 2004. Anaplasma infection in free-ranging Iberian

352 red deer in the region of Castilla-La Mancha Spain. Vet. Microbiol. 100, 163-173.

353

354 de la Fuente, J., Torina, A., Caracappa, S., Tumino, G., Furlá, R., Almazán, C., Kocan, K.M., 355 2005. Serologic and molecular characterization of Anaplasma species infection in farm

356 animals and ticks from Sicily. Vet. Parasitol. 133, 357-362.

357

358

359

360

361

362

363

364

365

366

367

368

369

370

de la Fuente, J., Atkinson, M.W., Naranjo, V., Fernández de Mera, I.G., Mangold, A.J., Keating, K.A., Kocan, K.M., 2007. Sequence analysis of the msp4 gene of Anaplasma ovis strains. Vet. Microbiol. 119, 375-381.

Dreher, U.M., Hofmann-Lehmann, R., Meli, M.L., Regula, G., Cagienard, A.Y., Stark, K.D.C., Doherr, M.G., Filli, F., Hassig, M., Braun, U., Kocan, K.M., Lutz, H., 2005a.

Seroprevalence of anaplasmosis among cattle in Switzerland in 1998 and 2003: No evidence of an emerging disease. Vet. Microbiol. 107, 71-79. 
372 Friedhoff, K.T., 1997. Tick-borne diseases of sheep and goats caused by Babesia, Theileria or 373 Anaplasma spp. Parassitologia, 39, 99-109.

374

375 Hajtós, I., 1982. Predisposing factors of sheep listeriosis in Northern Hungary. Magy.

376 Állatorvosok. 37, 819-823. (in Hungarian)

377

378 Kieser, S.T., Eriks, I.S., Palmer, G.H., 1990. Cyclic rickettsemia during persistent Anaplasma 379 marginale infection of cattle. Infect. Immun. 58, 1117-1119.

380

381 Kocan, K.M., de la Fuente, J., Guglielmone, A.A., Meléndez, R.D., 2003. Antigen s and

382 alternatives for con trol of Anaplasma marginale infection in cattle. Clin. Microbiol. Rev. 16, $383 \quad 698-712$.

384

385 Kuttler, K.L., 1984. Anaplasma infections in wild and domestic ruminants: a review. J. Wild1. 386 Dis. 20, 12-20.

387

388 Lew, A.E., Gale, K.R., Minchin, C.M., Shkap, V., Waal, D.T. de, 2003. Phylogenetic analysis

389 of the erythrocytic Anaplasma species based on 16S rDNA and GroEL (HSP60) sequences of

390 A. marginale, A. centrale, and A. ovis and the specific detection of A. centrale vaccine strain.

391 Vet. Microbiol. 92, 145-160.

392

393 More, T., Reddy, G.R., Sharma, S.P., Singh, L.N., 1989. Enzymes of oxidant defence system

394 of leucocytes and erythrocytes in bovine anaplasmosis. Vet. Parasitol. 31, 333-337. 
396

397

398

399

400

401

402

403

404

405

406

407

408

409

410

411

412

413 Rotruck, J.T., Pope, A.L., Ganther, H.E., Hoekstra, W.G., 1972. Prev ention of oxidative

414 damage to rat erythrocytes by dietary selenium. J. Nutr. 102, 689-696.

415

416 Sahoo, A., Patra, R.C., Pathak, N.N., Dwivedi, S.K., Dash, P.K., 2001. Enhanced lipid

417 peroxide levels in the erythrocytes of calves with haemoglobinuria. Vet. Res. Commun. 25,

$418 \quad 55-59$.

419

Palmer, G.H., Abbott, J.R., French, D.M., McElwain, T.F., 1998. Persistence of Anaplasma ovis infection and conservation of the $m s p-2$ and $m s p-3$ multigene families within the genus Anaplasma. Infect. Immun. 66, 6035-6039.

Papadopoulos, B., 1999. Cattle and small ruminant piroplasmos is in Macedonia, Greece.

Parassitologia, 41 (Supplement 1): 81-84.

Poncet, A., Chossonery, A., Brugère-Picoux, J., 1987. L'anaplasmose bovine. Bull. Soc. Vét Prat de France T. 71, 381-400.

Ramprabhu, R., Priya, W.S.S., Prathaban, S., Dhanapalan, P., 1999. Clinical and haematological profile of anaplasmosis in goats. Indian J. Small Ruminants 5, 49-51.

Reddy, G.R., More, T., Sharma, S.P., Singh, L.N., 1988. The oxidant defence system in water-buffaloes (Bubalus bubalis) experimentally infected with Anaplasma marginale. Vet. Parasitol. 27, 245-249. 
420 Sayin, F., Dyncer, S., Karaer, Z., Cakmak, A., Yukary, B.A., Eren, H., Deger, S.,

421 Nalbantoglu, S., 1997. Status of the tick-borne diseases in sheep and goats in Turkey.

422 Parassitologia 39, 153-156.

423

424 Sharma, S.P., 1988. Experimental Anaplasma marginale infection in sheep. Indian J. Vet.

425 Med. 8, 91-95.

426

427 Shompole, S., Waghela, S.D., Rurangirwa, F.R., McGuire, T.C., 1989. Cloned DNA probes

428 identify Anaplasma ovis in goats and reveal a high prevalence of infection. J. Clin. Microbiol.

$429 \quad 27,2730-2735$.

430

431 Splitter, E.J., Anthony, H.D., Twiehaus, M.J., 1956. Anaplasma ovis in the United States. Am.

432 J. Vet. Res. 17, 487-491.

433

434 Thompson, J.D., Higgins, D.G., Gibson, T.J., 1994. CLUSTAL W: improving the sensitivity

435 of progressive multiple sequence alignment through sequence weighting, positions-specific

436 gap penalties and weight matrix choice. Nucl. Acids Res. 22, 4673-4680.

437

438 Van Vleet, J.F., 1980. Current knowledge of selenium-vitamin E deficiency in domestic

439 animals. J. Am. Vet. Med. Assoc. 176, 321-325. 
Table 1. Blood biochemical parameters of sheep with (A, B) or without (C) haemoglobinuria

\begin{tabular}{lllll}
\hline Parameter & Normal value & Sheep A & Sheep B & Sheep C \\
\hline AST & $<60 \mathrm{U} / 1$ & 140 & 175 & 161 \\
\hline ALT & $<10 \mathrm{U} / 1$ & 16 & 30 & 54 \\
\hline bilirubin (total) & $<8 \mu \mathrm{mol} / 1$ & 2.2 & 1.7 & 7 \\
\hline ALP & $40-200 \mathrm{U} / 1$ & 382 & 295 & n.a. \\
\hline GGT & $10-30 \mathrm{U} / 1$ & 44.8 & 47.0 & 13.4 \\
\hline prote in (total) & $60-80 \mathrm{~g} / 1$ & 92.4 & 83.1 & 94.7 \\
\hline
\end{tabular}

Blood was collected 24 days and 2 days after haemoglobinuria in sheep A and B, respectively.

Sheep C was sampled at the same time as sheep B. Abbreviations: AST - aspartate aminotransferase, ALT - alanine aminotransferase, ALP - alkaline phosphatase, GGT gamma-glutamyl transpeptidase, n.a. - not available 
Table 2. Antibody levels of sheep in the Anaplasma spp. cELISA according to age group

\begin{tabular}{llllll}
\hline & \multicolumn{5}{c}{ age in years } \\
\cline { 2 - 6 } & $\mathbf{1 - 2}$ & $\mathbf{3}$ & $\mathbf{4}$ & $\mathbf{5}$ & $\mathbf{6 - 1 0}$ \\
\hline sample number & 19 & 38 & 27 & 23 & 34 \\
\hline mean inhibition value (\%) & 88.6 & 86.6 & 84.7 & 83.8 & 78.7 \\
\hline standard deviation & \pm 3.44 & \pm 5.30 & \pm 6.28 & \pm 8.50 & \pm 14.08 \\
\hline
\end{tabular}


Table 3. Nucleotide differences in nine positions ${ }^{\mathrm{b}}$ among $m s p 4$ sequences from $\mathrm{A}$. ovis isolates

\begin{tabular}{llllllllll}
\hline Sequence $^{\text {a }}$ & $\mathbf{3 0}$ & $\mathbf{1 3 9}$ & $\mathbf{1 7 8}$ & $\mathbf{2 7 0}$ & $\mathbf{2 8 7}$ & $\mathbf{3 0 2}$ & $\mathbf{4 3 8}$ & $\mathbf{4 7 0}$ & $\mathbf{5 4 9}$ \\
\hline EF190513 & T & A & T & G & A & T & G & T & G \\
\hline EF190509 & C & $*$ & $*$ & A & G & $*$ & A & C & C \\
\hline EF190510 & C & G & $*$ & A & $*$ & $*$ & A & C & C \\
\hline EF190512 & C & $*$ & C & $*$ & $*$ & C & A & $*$ & C \\
\hline EF190511 & C & $*$ & $*$ & $*$ & $*$ & $*$ & A & $*$ & $\mathrm{C}$ \\
\hline
\end{tabular}

${ }^{\mathrm{a}}$ GenBank accession number.

${ }^{\mathrm{b}}$ The numbers represent the nucleotide position starting at translation initiation codon adenine.

Conserved nucleotide positions with respect to the EF190513 are represented with asterisks. 